\title{
メタボリックシンドローム該当者の 健康教室効果の検討
}

\section{Effect of Health Classes for Metabolic Syndrome Patients}

\section{宮原 洋八1)}

\section{HIROYA MIYABARA ${ }^{1)}$}

1) Department of Physical Therapy, Faculty of Health, Tsukuba International University: 6-8-33 Manabe, Tsuchiura-shi, Ibaraki 300-0051, Japan. TEL+81 29-883-6023 E-mai h-miyabara@tius-hs.jp

Rigakuryoho Kagaku 25(6): 905-908, 2010. Submitted Jun. 8, 2010. Accepted Jul. 12, 2010.

ABSTRACT: [Objective] The purpose of this study was to investigate the effects of health classes for metabolic syndrome patients. [Methods] The subjects were 17 middle-aged men and women (age: $57.9 \pm 6.3$ years). The training program consisted of guidance (walking, nourishment, action, support etc) for 8 weeks. We measured total cholesterol (TC), triglyceride (TG), high density lipoprotein (HDL), glucose (GUL), body fat volume, abdominal circumference, steps, and breath holding time before and after the 8-week training period. [Results] TC and TG showed a significant decrease $(p<0.01)$ and steps showed a significant increase after the training period $(p<0.05)$. [Conclusion] These results suggest that the training program for metabolic syndrome patients improves blood chemistry and increases steps.

Key words: health class, metabolic syndrome, self-efficacy

\footnotetext{
要旨：〔目的〕メタボリックシンドローム該当者を，3ケ月間で 8 回の健康教室を実施し，その効果を検討すること を目的とした。[対象〕メタボリックシンドローム該当者の男女 17 人 (平均年齢 : $57.9 \pm 6.3$ 歳) とした。〔方法〕教 室の前後で, 身長, 体重・体脂肪率, 腹囲, 血圧, 血液検査（総コレステロール，中性脂肪，HDLコレステロール， 空腹時血糖), Health Practice Index, 運動後息こらえテストを測定した。〔結果〕教室開始前後でメタボリックシン ドロームの構成因子の1つである総コレステロールと中性脂肪が有意に改善された。また一日の平均歩数が有意に 増加した。[結語〕教室参加者の自己効力感を高めるように運動を継続させることが重要であることが示唆された。 キーワード : 健康教室, メタボリックシンドローム, 自己効力感

1)つくば国際大学 医療保健学部理学療法学科 : 茨城県土浦市真鍋6-8-33（テ300-0051）TEL 029-883-6023

受付日 2010年6月8日 受理日 2010年7月12日
} 


\section{I.はじめに}

奄美大島は，温暖な気候（平均気温 21 度），島歌地 区，豊かな食文化（黒砂糖，豚足，魚介類）など健康・ 長寿に関連の深い多様な資源を有しており，平成 15 年 9 月現在の人口 10 万人当たりの 100 歳以上の者は 66 人と 沖縄県の 42 人より高い水準にある。しかし, 若年世代 を中心に食生活の西洋化, 日常生活のあらゆる面にわ たる本土化にともなうモータリゼーションの普及によ る運動不足, ストレスの増加1) など今後の健康面への 影響が危惧される。一方, 平成 12 年度から厚生労働省 は, 人口の急速な高齢化とともに生活習慣病およびこ れに起因して要介護状態になる者の社会問題に対して 「21 世紀における国民健康づくり運動」（通称「健康日 本21」2)）を開始した。奄美においても笠利町役場いき いき健康課が住民の健康づくりに対する意識を高めて いく事を目標に「健康かさり21」計画が策定された1)。 具体的には生活習慣（食生活, 運動, 休養など）を見 直しそれぞれ数值目標を住民自らで決定させた。しか しながら, この「健康かさり21」を受けて笠利町役場 いきいき健康課が健康教室を開催しても, 参加者が離 脱するために, 教室前後の効果について検討すること ができなかった。本研究では, 平成 19 年度基本健康診 查（以下, 健診と略す）の項目の中でメタボリックシ ンドローム該当者に, 笠利町主催の健康教室に平成 19 年 10 月から 3 ケ月間参加させ, その効果を教室前後で 検討したので報告する。

\section{II. 対象と方法}

1. 対象

平成 19 年 6 月に鹿児島県奄美市笠利保健センターに おいて健診を受けた 40 歳以上の受診者 305 人から, 内 臓肥満（腹囲が男性で $85 \mathrm{~cm}$ 以上，女性で $90 \mathrm{~cm}$ 以上） に該当し, 脂質異常 (HDL コレステロール低值 $<40 \mathrm{mg} /$ $\mathrm{dl}$ ，かつ中性脂肪 $\geqq 150 \mathrm{mg} / \mathrm{dl}$ )，血圧高值（収縮期血圧 $\geqq 130 \mathrm{mmHg}$ かつ $\geqq$ 拡張期血圧 $8 \mathrm{mmHg}$ ), 高血糖（空腹 時血糖 $110 \mathrm{mg} / \mathrm{dl}$ 以上）のうちの 2 項目以上がある場合 をメタボリックシンドロームと判定した ${ }^{3}$ 健診の結果 から，メタボリックシンドロームに該当した 87 人を対 象とし, 健康ゲンゲン教室（以下, 教室と略す: 資料 1 参照）の参加を個人通知，電話にて行ったところ 20 人 が応募した。6ケ月間を通して8回す心゙ての教室に参加 した男女 17 人 (平均年齢 $57.9 \pm 6.3$ 歳) を本研究の対象 とした (表1)。なお, 参加者には健康教室開始時に, 趣 旨，内容および測定結果の取り扱いなどについて説明 を行い，同意を得た。

\section{2. 方法}

教室は，3ケ月間に合計8回の教室を開催した。主な 内容は (資料 1), (1)医師, 栄養士, 理学療法士により それぞれメタボリックシンドロームの概念の話，栄養 指導や食事記録日誌の活用法, 日常生活で身体活動を 高める運動の話。(2)保健師が, 参加者の継続化一の働 きかけとしてグループワーク・セルフモニタリング・ 目標設定などを支援する。(3)測定結果については，保 健師が，個別的にアドバイスを行う。(4)参加者全員に 自らの身体活動量の指標を知らせるため歩数計を貸し
表1 対象

\begin{tabular}{lc}
\hline 症例数 & 17 \\
年齢(歳) & $57.9 \pm 6.3$ \\
性別 $($ 男/女) & $6 / 11$ \\
身長 $(\mathrm{cm})$ & $154.1 \pm 5.9$ \\
体重 $(\mathrm{kg})$ & $65.2 \pm 6.9$ \\
最高血圧 $(\mathrm{mmHg})$ & $129.4 \pm 11.0$ \\
最低血圧 $(\mathrm{mmHg})$ & $76.8 \pm 10.2$ \\
\hline
\end{tabular}

$\mathrm{AVE} \pm \mathrm{SD}$
資料1 平成19年度笠利町健康ゲンゲン教室

\begin{tabular}{|c|c|c|c|}
\hline & 日程 & 内容 & 担当 \\
\hline 第1回 & 10 月 5 日 (金) & $\begin{array}{l}\text { 教室ガイダンス } \\
\text { 血液採取・形態,息こらえ測定自記式アンケート } \\
\text { 歩数計の使用法,セルフモニタリング記入法 }\end{array}$ & 保健師 \\
\hline 第2回 & 10 月 12 日 (金) & $\begin{array}{l}\text { メタボリックシンドロームについて講義 } \\
\text { 日常生活の中で身体活動を高めるはなし }\end{array}$ & $\begin{array}{l}\text { 医師 } \\
\text { 理学療法士 }\end{array}$ \\
\hline 第3回 & 10 月 19 日 (金) & $\begin{array}{l}\text { グループワーク・目標設定 } \\
\text { 健診の結果指導 }\end{array}$ & 保健師 \\
\hline 第4回 & 11月2日 (金) & 食事記録日誌の活用法栄養指導 & 栄養士 \\
\hline 第5回 & 11月 16 日 (金) & ウォーキング実技指導 & 理学療法士 \\
\hline 第6回 & 11月 30 日 (金) & 健康メニュー実習 & 栄養士 \\
\hline 第7回 & 12月7日 (金) & 行動目標の支援 & 保健師 \\
\hline 第8回 & 12月 21 日 (金) & 血液採取・形態, 息こらえ測定 & 保健師 \\
\hline
\end{tabular}


出し，1日の歩数を記録させる（歩数は教室開始 1 週間 前から第 2 回までの平均歩数/日, 教室期間中（第 3 回 から第 8 回）の平均歩数/日)。教室開始 1 週間前と終了 1 週間後で，身長，体重・体脂肪率（TANITADC-320S）， 腹囲 (市販のメジャー), 血圧 (収縮期血圧, 拡張期血 圧), 血液検查（総コレステロール, 中性脂肪, HDL コ レステロール, 空腹時血糖 : 奄美市医師会臨床検査セ ンターに依頼）を測定した。第3回目の教室終了後に自 記式アンケート（身体活動を高める運動の目標はある か, Breslow の 7 つの健康習慣 $\left.{ }^{4}\right)$ それぞれの良い習慣 （1）と悪い習慣（0）に分け2 分法で 0 または 1 を得点と し，その合計をHealth Practice Index ${ }^{5}$ （以下, HPI と略す る）とした。心肺持久性は運動後息こらえテスト6)を 測定した。運動後息こらえは, 一定の運動負荷を与え た後（毎秒 3 回のテンポでその場馸足を 1 分間行う）に 息を止めてその時間を計測する。解析は, 教室に参加 した男女の比較に対応のない $\mathrm{t}$ 検定, 教室前後での測 定項目の比較に対応のある $\mathrm{t}$ 検定, アンケート項目を 2 群に分け, 歩数と比較するため, 対応のない $\mathrm{t}$ 検定 を行った。有意水準はいずれも5\%未満とした。

\section{III. 結 果}

教室に参加した男女の比較では, 体脂肪率において 男性より女性が有意に大きく $(\mathrm{p}<0.01)$, 血糖值におい ては女性より男性が有意に大きく $(\mathrm{p}<0.01)$, 歩数は男 性より女性が有意に多かった（p<0.05）（表 2）。教室前 後の測定值の変化では, 中性脂肪, 総コレステロール が有意に減少し $(\mathrm{p}<0.01)$, 歩数は 8,970 歩から 12,058 歩 へ, 有意に増加した $(\mathrm{p}<0.05)$ （表3）。アンケートで, 運動に関して「目標あり」「目標なし」, HPI 「4-7点」「3 点以下」と歩数の比較では, 「目標あり」（ $<<0.05 ） 「 4-7$ 点」（p<0.01）の歩数が有意に多かった（表 3$)$ 。

\section{IV. 考 察}

肥満, 高血圧, 糖尿病, 高中性脂肪血症は生活習慣 病とも言われるが, これら4つを伴った場合には動脈 硬化性血管合併症のリスクが著しく高くなるため, 「死 の四重奏」または「メタボリックシンドローム」と呼 ばれる77。笠利町における調査1 ステロール, 高血糖の有所見率は, 鹿児島県 ${ }^{8)}$ や沖縄 県より 9) も高い值を示した。昭和 29 年から今日まで奄 美群島振興開発特別措置法 ${ }^{10)}$ により, 現在の奄美は生 活環境整備が本土並みとなり, 自家用車の保有台数も
表2 男女の測定值比較（男性 $n=6$, 女性 $n=11$ ）

\begin{tabular}{|c|c|c|}
\hline & 男性 & 女性 \\
\hline 身長 (cm) & $157.8 \pm 7.0$ & $152.0 \pm 4.2$ \\
\hline 体重 (kg) & $68.8 \pm 5.7$ & $63.3 \pm 7.0$ \\
\hline 体脂肪 (\%) & $23.9 \pm 2.1$ & $35.6 \pm 3.3$ \\
\hline 腹囲 $(\mathrm{cm})$ & $93.5 \pm 3.7$ & $92.4 \pm 5.4$ \\
\hline 総コレステロール $(\mathrm{mg} / \mathrm{dl})$ & $231.0 \pm 64.6$ & $224.7 \pm 28.0^{* *}$ \\
\hline 中性脂肪 (mg/dl) & $156.5 \pm 99.9$ & $140.8 \pm 78.4^{* *}$ \\
\hline $\mathrm{HDL}$ コレステロール $(\mathrm{mg} / \mathrm{dl})$ & $60.9 \pm 18.8$ & $59.7 \pm 15.2$ \\
\hline 血糖 (mg/dl) & $121.6 \pm 48.3$ & $104.3 \pm 15.9$ \\
\hline 歩数 (歩) & $1856.9 \pm 335.7$ & $3735.0 \pm 1401.7^{*}$ \\
\hline
\end{tabular}

$\mathrm{AVE} \pm \mathrm{SD}$

${ }^{*} \mathrm{p}<0.05,{ }^{* *} \mathrm{p}<0.01$

表3 教室前後での健診結果の比較 $(\mathrm{n}=17)$

\begin{tabular}{lcc}
\hline & 教室前 & 教室後 \\
\hline 体脂肪 $(\%)$ & $31.4 \pm 6.4$ & $31.9 \pm 6.2$ \\
腹囲 $(\mathrm{cm})$ & $92.8 \pm 4.7$ & $91.3 \pm 5.7$ \\
総コレステロール $(\mathrm{mg} / \mathrm{dl})$ & $239.4 \pm 43.1$ & $226.9 \pm 42.5^{* *}$ \\
中性脂肪 $(\mathrm{mg} / \mathrm{dl})$ & $146.3 \pm 83.8$ & $125.8 \pm 68.1 * *$ \\
$\mathrm{HDL} コ$ & $60.1 \pm 16.0$ & $62.3 \pm 15.6$ \\
血糖 $(\mathrm{mg} / \mathrm{dl})$ & $110.4 \pm 31.0$ & $111.7 \pm 39.7$ \\
歩数(歩) & $8970.8 \pm 2039.2$ & $12058.1 \pm 1954.0^{*}$ \\
息こらえ(秒) & $24.2 \pm 9.0$ & $25.1 \pm 6.6$ \\
\hline
\end{tabular}

$\mathrm{AVE} \pm \mathrm{SD}$

${ }^{*} \mathrm{p}<0.05, * * \mathrm{p}<0.01$

表4 アンケート結果の比較 $(\mathrm{n}=17)$

\begin{tabular}{lcc}
\hline & 目標あり & 目標なし \\
\hline 歩数 (歩) & $13540.0 \pm 1842.0$ & $5141.1 \pm 1954.7^{*}$ \\
\hline & HPI 7-4点 & HPI 4-0点 \\
\hline 歩数 (歩) & $6633.2 \pm 580.9$ & $1372.3 \pm 2208.6^{*}$ \\
\hline $\mathrm{AVE} \pm \mathrm{SD}$ & & \\
$* \mathrm{p}<0.05$ & &
\end{tabular}

多い。またここ数年の間に大型スーパーやファース トフード店も進出してきた。若年層で「肉, ハンバー グ, ソーセージを週 2 回以上食べる」習慣が高いこと （男性 $69.7 \%$ ，女性 $62.6 \%$ ） や本来奄美は亜熱帯特有の テゲテゲ精神（おおらかでくよくよしない）である（高 年層（男性 $15.8 \%$ ，女性 19.0\%）はずが若年層（男性 27.0 $\%$ ，女性 $30.2 \%$ ）や中年層（男性 $28.4 \%$ ，女性 $26.0 \%$ ） で「ストレスを毎日感じる」が高かった1)。近年まで奄 美は沖縄と並んで長寿島として知られてきたが，本土 復帰後, 生活習慣も本土化してきたために若年層や中 
年層から健康状態が変化してきたと考えられる。これ らを踏まえて, 本研究では, メタボリックシンドロー 厶該当者を対象に絞り，3ヶ月間の健康教育（ハイリス クアプローチ）を実施し，その効果を検討した。その 結果, 教室開始前後でメタボリックシンドロームの構 成因子の 1 つである中性脂肪が改善された。国内の介 入研究は, 野田ら ${ }^{11)}$ が肥満者を対象に高度介入群（栄 養・健康相談, 週 3 回の運動) の 59 人（平均年齢 49.5 歳), 中等度介入群（栄養・健康相談, 週 1 回の運動）の 62 人 (平均年齢 51.1 歳), 対照群（保健事業のみ）の 34 人 (平均年齢 51.9 歳) の 3 群に分け，6r月にわたり介 入効果を検討した結果, 両介入群で脂質スコアと運動 時間に有意な改善が認められたと報告している。米国 では, Orchard ら ${ }^{12)}$ が生活習慣介入群と対照群の間に, 1 年後メタボリックシンドロームの累積発症率の差が 見られたと報告している。本研究では, 対照群を設け なかったので, 厳密には各指標の変化が教室の効果と は言えない。しかしながら参加者に, 保健センターの スタッフが個人の特性や嗜好にあった個別健康教育を 行い, 実施期間中, 参加者が脱落しないように教室の 前には, 毎回電話をかけた。また, 継続化への働きか けとして, 参加者全員にセルフモニタリングノートが 配布され, 毎日体重, 歩数を記入させ, 目標を達成し たかチェックさせた。そして教室終了時には，3个月間 の平均歩数が上位 1 番, 2 番の人を表彰し, 動機づけを した。本研究において, 短期間の教室でも参加者に目 標を持たせ，生活習慣を良くさせるように教育し，動 機づけをすることが重要であることが示唆された。

\section{引用文献}

1) 笠利役場いきいき健康課 : 健康かさり 21,2000 , 鹿児島.

2) 厚生労働省健康局総務課生活習慣病対策室 : 21 世紀における 国民健康づくり運動（健康日本21）と健康増進法について. 理学療法ジャーナル, 2004, 38(6): 433-439.

3) メタボリックシンドローム診断基準検討委員会: メタボリッ クシンドロームの定義と診断基準. 日本内科学会雑誌, 2005, 94: 794-809.

4) Bellok NB, Breslow L: Relationship of physical health status and health practices. Preventive Medicine, 1972, 1: 409-421.

5) 森本兼䡛 (編) : ライフスタイルと健康. 医学書院, 1991, 東京.

6) 東京都立大学体力標準值研究会編: 新日本人の体力標準值 2000. 不眜堂出版, 2000, 東京.

7) 若林一郎 : 定期健康診断の結果からみた山形県内の産業従事 者の血中脂質異常について。秋田県公衆衛生学雑誌，2005, 2(1): 7-11.

8) 鹿児島県保健福祉部健康増進課 : 鹿児島県の生活習慣病）資 料編). 2000, 鹿児島.

9) 桑江なおみ，下地実夫，浜里啓子・他：沖縄県における性 別, 年代別BMI, 血圧, 総コレステロール, 血糖の平均值お よびハイリスク者の割合。沖縄県衛生環境研究所報, 2002, 36: 99-107.

10) 吉田慶喜 : 奄美の振興開発。あまみ庵，1995,鹿児島.

11）野田博之, 原田美知子, 横田紀美子・他：地域における過体 重・肥満者を対象とした運動施設利用, 栄養指導による個別 健康教育と介入効果の検討. 日本公衛誌，2006, 53(10): 749761.

12) Orchard TJ, Temprosa M, Goldberg R, et al.: The effect of metformin and intensive lifestyle intervention on the metabolic syndrome: the diabetes prevention program randomized trial. Ann Intern Med, 2005, 142: 611-619. 